\title{
Relationships between benthic macrofauna and habitat suitability for juvenile common sole (Solea solea, L.) in the Vilaine estuary (Bay of Biscay, France) nursery ground
}

\author{
D. Nicolas ${ }^{a,{ }^{\star}}$, F. Le Loc'h ${ }^{b}$, Y. Désaunay ${ }^{c}$, D. Hamon ${ }^{d}$, A. Blanchet ${ }^{d}$ and O. Le Pape ${ }^{a}$ \\ a Pôle halieutique, Agrocampus Rennes, 65, rue de Saint-Brieuc, CS 84215, 35042 Rennes Cedex, \\ France \\ ${ }^{b}$ IRD, UR RAP, Centre de Recherche Halieutique, Avenue Jean Monnet, B.P. 171, 34203 Sète \\ Cedex, France \\ ${ }^{c}$ IFREMER, EMH, rue d'Ile d'Yeu, B.P. 21105, 44311 Nantes Cedex, France \\ d IFREMER, DYNECO/Ecologie benthique, Centre de Brest, BP 70, 29280 Plouzané, France \\ *: Corresponding author :
}

\begin{abstract}
:
Coastal and estuarine systems are among the most threatened by human activities which damage their ecological function and, in particular, their nursery role for many marine species. In this context, the protection of these vital ecosystems is a critical issue for the management of fisheries resources. To that aim, functional approaches have to be developed that make it possible to assess habitat suitability and quality. The common sole, Solea solea (L.) was selected as an indicator species to identify the features of coastal and estuarine nursery habitats in the Bay of Biscay (France).

Previous studies have shown that young-of-the-year (YOY) sole are strongly dependent upon various abiotic factors, and especially bathymetry, sediment cover and the extent of river plumes. We investigated whether taking into account biological variables, based on benthic macrofauna biomasses aggregated into trophic group, may improve the description of the juvenile sole distribution in the Vilaine estuary nursery. Results from Generalised Linear Models demonstrated the importance of integrating these biological variables in the determination of juvenile habitats at a local scale. The abundance of YOY sole was correlated with an index of the benthic invertebrates biomass and, more specifically, with the biomass of suspension feeders. This result was reinforced by a one-dimensional spatial statistical analysis, which pointed out the similar distribution of invertebrate macrobenthos and juvenile sole along the upstream/downstream gradient of the estuary. Moreover, the inter-annual variations of abundance and distribution of juveniles were synchronous with those of the macrobenthos.
\end{abstract}

Keywords: Solea solea; nursery ground; essential fish habitat; benthic macrofauna; functional indicators; Vilaine estuary 


\section{Introduction}

Coastal and estuarine systems are essential habitats for the renewal of fisheries resources, because they provide nursery grounds for many marine species of the continental shelf (Beck et al., 2001; Able, 2005). Of particular interest are nursery habitats for commercially important flatfishes (Koutsikopoulos et al., 1989; van der Veer et al., 2000). Juvenile growth and survival, hence recruitment into adult populations, are greatly determined by the quality of these nursery habitats (Gibson, 1994; Le Pape et al., 2003a). But over the past decades, these coastal and estuarine nursery grounds are increasingly exposed to anthropogenic impacts (e.g. land reclamation, pollution, eutrophication and introduction of invasive species; Antunes and Santos, 1999; Elliott and Hemingway, 2002; McLusky and Elliott, 2004), at a time when most adult fish stocks are stressed by fisheries (Worm et al., 2006). Due both to fishing or to other indirect human effects, there are changes in biological communities and fish diversity may become unbalanced (Levin et al., 2006). As a consequence, the protection of these essential fish habitats represents a crucial issue for ecosystem management (Beck et al., 2001). Determining optimal nursery habitats, assessing their environmental quality and also supporting decisions in management and conservation plans require standardised diagnostic tools, such as integrated ecological indicators that are related to fish habitat function (Rubec et al., 1999; Adams, 2002; Whitfield and Elliott, 2002).

In the Bay of Biscay (Atlantic coast of France), the common sole Solea solea (Linnaeus, 1758) is one of the most exploited species (Anonymous, 2003). Spawning occurs from January to April between 50 and $100 \mathrm{~m}$ depth, $80 \mathrm{~km}$ off the coast (Koutsikopopoulos et al., 1989). Only a small proportion of pelagic larvae drift successfully to shallow estuaries and coastal areas. Post larval individuals settle from February to May on inshore areas (Amara et al., 2001), where they switch on to a benthic lifestyle where they feed at night on small benthic invertebrates (polychaetes, bivalves, crustaceans, etc.) (Amara et al., 2001). Juvenile sole depend on shallow nurseries for about two years, (Koutsikopopoulos et al., 1989) before they join the offshore mature adult population (Dorel et al., 1991). Previous studies in the Bay of Biscay, and particularly in Vilaine Bay, show relationships between the distribution of juvenile common sole and physical factors. Young-of-the-year (YOY) sole are found to be more numerous on shallow and soft bottom areas of estuarine and semi-enclosed parts of the coast (Le Pape et al., 2003b). The extent of sole nursery grounds in Vilaine Bay is also shown to be influenced by the variability of the river flow (Le Pape et al., 2003c).

Models of habitat suitability which take into account only physical descriptors lead to a great part of non explained variability (Le Pape et al., 2003b), and do not allow a qualitative assessment of nursery habitats. To develop reliable indicators of sole nursery habitat, it is important to integrate biological variables that are related to benthic fauna for two main reasons (Peterson et al., 2000):

- First, the distribution of juvenile flatfishes is naturally influenced by the quality of the invertebrate benthic community, which constitutes their food supply (Gibson, 1994; Howell et al., 1999). In addition, over the scale of main nurseries in the Bay of Biscay, Le Pape et al. (2007) have demonstrated a relationship between the distribution of deposit and suspension feeders of the trawled benthic fauna and juvenile common sole. These macrobenthic descriptors are based on the small fraction of epibenthos that could be collected by beam trawl, and thus, are not reliable to assess benthic density or biomass. Nevertheless, they improved the models of nursery habitat suitability, both at meso and local scales.

- Secondly, because benthic fauna are intimately related to sediment, which accumulates sources of enrichment and pollution, they constitute an indicator of environmental quality (Grall and Glémarec, 1997; Peterson et al., 2000; Salas et al., 2004).

The purpose of the present study in the Vilaine estuary was to develop habitat suitability index (HIS) based on benthic macrofauna communities to describe the abundance and spatial distribution of juvenile sole, in order to determine essential nursery habitats. Thus, links between benthic macrofauna collected by grab sampling and trawled YOY sole were evaluated (densities and distributions). Contrary to the previous study Le Pape et al. (2007), the present investigation was based on macrobenthic infauna instead of epifauna communities. Applying generalised linear models, benthic descriptors of the nursery function were employed as descriptors of juvenile sole densities, in addition to the physical factors known to influence YOY sole distribution (i.e. sediment structure and depth). Moreover, a spatial analysis was done to examine the spatial covariation between macrobenthos and juvenile sole. 


\section{Materials \& Methods}

\subsection{Situation of study area: the Vilaine estuary}

The Vilaine estuary is located on a shallow coastal inlet of the northern Bay of Biscay (Fig. 1), and is protected from open ocean by a threshold of islands and shallow grounds (Le Bris and Glémarec, 1996). Mud and soft fine sand mainly cover the bottom of the bay and estuary (Le Bris and Glémarec, 1996). In this estuary, the tide is blocked by the Arzal dam, which is located $10 \mathrm{~km}$ upstream the river mouth (Fig. 1). The annual mean flow of the Vilaine River is $68 \mathrm{~m}^{3} . \mathrm{s}^{-1}$ (Le Bris and Glémarec, 1996), but varies greatly as a function of rainfall and dam managment, with considerable seasonal and interannual fluctuations (Le Pape et al., 2003c). The Vilaine estuary shelters an important nursery ground for the common sole within the Bay of Biscay (Koutsikopoulos et al., 1989).

\subsection{Sampling strategy}

Two sampling surveys were undertaken in mid-July 2004 and 2005, just after the completion of estuarine colonization by YOY sole (Marchand, 1991). Mid-July is a representative sampling period to assess the annual young sole production and distribution for two reasons. First, juvenile survival during the first post-settlement phase is the most important determing factor explaining fluctuations in adult population size, after variations in larval supply (Amara et al., 2001; Levin and Stunz, 2005). Secondly, during their first summer, juvenile sole have a very low mobility and their distribution pattern remains relatively fixed (Dorel et al., 1991). Hence, July samples are representative of the summer growth period.

Surveys occurred on similar neap tidal conditions. The study area $\left(47^{\circ} 28^{\prime}-47^{\circ} 31^{\prime} \mathrm{N} / 2^{\circ} 23^{\prime}-\right.$ $2^{\circ} 36^{\prime} \mathrm{W}$ ) included the Vilaine estuary and the north-western part of the bay, i.e. part adjacent to the river mouth (Fig. 1). Juvenile sole were caught by a beam trawl with an opening $2.9 \mathrm{~m}$ wide and $0.5 \mathrm{~m}$ high and with a $10 \mathrm{~mm}$ stretched mesh net codend. Within the same period, sediment and associated macrofauna were sampled with a van Veen grab $\left(0.1 \mathrm{~m}^{2}\right)$. Beam trawls and grab stations were designated according to a stratified-random design from Arzal dam to open ocean, and were located by Global Positioning System (GPS). Along this upstream/downstream estuary gradient, two relatively distinct areas can be recognized, taking into account the bathymetry, the sediment cover (Le Bris and Glémarec, 1996), and the distance from the river mouth (Le Pape et al., 2003c): the muddy inner estuary and river mouth of Vilaine and, further off, the sandy muddy outer estuary. The inner estuary and the river mouth areas are shallow (between 0 and less than $5 \mathrm{~m}$ depth), while the external estuary area is a little deeper (around $5 \mathrm{~m}$ depth) (Fig. 1).

Eleven beam trawl hauls were performed in 2004, and seven in 2005 (Fig. 1). Hauls were carried out at 2.5 knots for 15 min (each covering $3400 \mathrm{~m}^{2}$ on average). In the inner estuary, hauls were strictly completed inside the channel, it being impossible to trawl on the very shallow muddy banks. For each haul, trawled sole were counted and measured to estimate their age. Sole densities were spatially reported to the centre of each beam trawl haul (Fig. 2).

Eleven grab stations were sampled in 2004 and ten in 2005 (Fig. 1). Using a geographic information system (GIS), each grab station was automatically associated with the nearest trawl haul, so that it corresponded to a sole density. Hence, one trawl haul is associated with several grab stations. Five grab replicates per station were taken, sieved through $1 \mathrm{~mm}$ square mesh and preserved in formalin until laboratory analysis.

Bathymetric data (from the map of the Service Hydrographique et Océanographique de la Marine, France, scale $=1 / 500,000$ showing the coastline and 0,5 and $10 \mathrm{~m}$ isobaths) and the type of sediment cover (mud or sand), were taken from Le Bris and Glémarec (1996), and were associated to each trawl haul. At each grab station, one sediment sample was obtained and analyzed with granulometric measures to validate the Le Bris and Glémarec (1996) information.

\subsection{Benthic macrofauna samples}

Grab samples were sieved and then benthic macrofauna were sorted and extracted from sediment particles. Rose bengal was used to facilitate the detection of the smallest individuals. Organisms were identified to the lowest possible taxonomic level (generally to the species level). The species nomenclature followed here is the "European Register of Marine Species" (Costello et al., 2001). Abundance (number of individuals) per taxon was measured. Only three of the five replicates were analysed, because of the low variability of density between samples, except at the river mouth (five replicates) and for one station within the outer estuary area (four replicates), both in 2004. A total of 74 benthic macrofauna samples were analysed. Megafaunal individuals (greater than $10 \mathrm{~mm}$ in size, Mya arenaria and Carcinus maenas) were eliminated in order not to skew the biomasses. For each station, biomass of each taxon was measured by weight loss after combustion of dried material at $450^{\circ} \mathrm{C}$ for 4 hours (ash-free dry weight). Then taxa were aggregated into trophic groups according 
to the ecotrophic guilds method (Luczkovitch et al., 2002), to synthetically characterise benthic communities from a functional point of view. Based on the methods of Grall and Glémarec (1997) and Hily and Bouteille (1999), each taxon was allocated in one trophic group (carnivore, suspension feeder, selective deposit feeder, non-selective deposit feeder, detritivore, micrograzer or scavenger, Table 1). Being low in numbers, strict scavengers were pooled with carnivorous organisms that can also behave occasionally as scavengers. Finally, biomasses were summed per trophic group, and expressed as $\mathrm{mg} / \mathrm{m}^{2}$ for each grab replicate.

\subsection{Data analysis}

Generalized linear models (GLM), which integrate both physical and biological descriptors, were developed to analyse the distribution of YOY sole densities. The function $\mathrm{g} / \mathrm{m}$ on the R software (2006) was used. To avoid problems linked to the presence of null values (12\%), and regarding previous results related to their structural distribution (Le Pape et al., 2003b), YOY sole densities were described with a delta model. Presence/absence and positive density values, which corresponded to beam trawl hauls having caught at least one YOY sole, were treated in two different models (Le Pape et al., 2003b, Table 2):

- the likelihood of YOY sole presence $\left(P_{0 / 1}\right)$ was estimated by a GLM based on a binomial law:

$$
\mathrm{P}_{0 / 1} \sim \text { Factor } 1+\text { Factor } 2+\ldots+\text { Factor } \mathrm{n}+\varepsilon_{0 / 1}
$$

Where $[1,2, \ldots, n]$ correspond to the number of introduced factors and $\varepsilon_{0 / 1}$ represents the random error term, supposed to be independent from explicative factors and having a normal distribution.

- the log-transformed positive values of YOY sole densities Log(Dens+) was estimated by a Gaussian model:

$$
\log (\text { Dens }+) \sim \text { Factor } 1+\text { Factor } 2+\ldots+\text { Factor } n+\varepsilon_{+}
$$

The more explanatory factors used, the better the adjustment quality of the model, but the lesser the robustness of the model. Consequently, for each model, the number of introduced factors was limited (parsimony principle). Only variables which were positively linked to juvenile sole densities were tested in an ecologically significant order (Table 2).

- Firstly within models, the first introduced descriptor was a physical qualitative factor combining the bathymetry and the sediment cover. This physical factor consisted of the 4 followed classes: [intertidal zone/mud]; [0-5 m depth/mud]; [0-5 m depth/sandy mud]; [5-10 m depth/sandy mud].

- Secondly, one biological covariate related to the trophic groups of benthic macrofauna was integrated. The biological covariates (continuous linear predictors) were expressed in biomass $\left(\mathrm{mg} / \mathrm{m}^{2}\right)$ by trophic groups. To stabilise the variability of their biomasses and to correct their heteroscedasticity, we applied the logarithmic transformation $\log (x+1)$ to the data.

Models were alternatively tested with and without taking into account the interannual variability (as a first introduced factor).

Models were performed at the scale of the study area (models 1 and 2, Table 2), and then narrowed to the muddy compartment inside the estuary, which corresponded to the core of the nursery (models 3 and 4). For each model, we analyzed the part of deviance explained by each significant explanatory factor ( $5 \%$ level). We selected the best model based on Akaïke Information Criterion (AIC, Sakamoto et al., 1986): when comparing fitted models, the smaller the AIC, the better the fit. In addition, the validity of modelisation hypothesis (independence, normality of the residuals) was controlled and confirmed.

In a second quantitative approach, a one-dimensional spatial analysis was carried out to analyse the relationship between the respective distributions of juvenile sole and biotic factors. Both juvenile sole density and macrofauna biomasses (response variables) were separately described in relation with the distance to the dam (explicative variable). The Loess' smoothing method was applied with the function loess.smooth under R software (2006). The degree of smoothing was fixed to consider only the overall trends of variables and to obtain standardized smoothed curves. Separate graphs were created for July 2004 and 2005 to look at interannual covariation between benthic variables and YOY sole densities. 


\section{Results \\ 3.1. Benthic macrofauna community}

Within benthic macrofauna samples, 125 taxa were determined to species and 17 to family. The trophic group associated to each identified taxon is shown in Table 1; 45 taxa are known to essentially behave as carnivorous (including scavengers), 30 as suspension feeders, 38 as selective deposit feeders and 10 as non-selective deposit feeders.

In accordance with Le Bris and Glémarec (1996), along the upstream/downstream estuary, different communities of benthic macrofauna were observed with respect to the salinity gradient and the sediment structure. The inside muddy estuary community had low diversity and was mainly colonized by dense populations of suspensive feeder bivalves (e.g. Cerastoderma glaucum and Macoma balthica) and micrograzer gastropods (Hydrobia ulvae). Further away from the dam, the muddy river mouth area was richer in species, with the carnivorous polychaete Nephtys hombergii dominating. Lastly, the sandy external estuary area (Fig. 1), which has the most heterogeneous substratum, had the highest species richness with all associated trophic groups (except micrograzers) being present. Within this open ocean zone, abundance and total biomass were much lower compared to the inner estuary.

\subsection{Density and spatial distribution of juvenile sole catches}

For the two sampling years, trawled YOY sole were abundant inside the estuary, while almost none were found in the open ocean area (Fig. 2). Moreover, in July 2005, trawled juvenile sole were more numerous and the maximum of the catches was shifted downstream toward the estuary mouth, compared to July 2004.

\subsection{Models of young-of-year sole density}

At the study area scale, presence (binomial model) and abundance (positive model) of juvenile sole were mainly explained by the physical variable (with respectively approximately $52 \%$ and $68 \%$ of explained deviance in model 1, Table 2). There is indeed a strong contrast between estuarine nursery grounds, where YOY sole were numerous and always present, and offshore deeper areas, where YOY sole were scarce or totally absent.

Nonetheless, at this large scale, the fit of the binomial model was improved by the additive introduction of total macrobenthic biomass and especially of carnivore biomass, which explained about $53 \%$ of the residual deviance of the GLM (26\% of the total deviance, model 1). In the positive model, integrating total biomass of benthic invertebrates or suspensive filter feeders also resulted in significant improvement (approximately $15 \%$ of the residual deviance and $5 \%$ of the total deviance, model 1). The signal obtained by these significant biological covariates is less important when interannual variability is taken into account (approximately $9 \%$ of the residual deviance and $2 \%$ of the total deviance in model 2). All other biological descriptors (deposit feeders, micrograzers, detritivores) were never significant covariates within these models.

At the restricted muddy compartment (the core of the nursery) scale (models 3 and 4, Table 2), the binomial model became useless, as juvenile sole were always present, i.e. they were caught in all beam trawl hauls. Moreover, because this area is physically homogenous (shallow and muddy), the positive model did not include the physical variable. Without the physical variable, the model had two significant biological covariates: biomass of total benthic macrofauna or suspension feeder (14\% of the total deviance, model 3). In model 4, where interannual variability is integrated (approximately 15 $\%$ of the total deviance), these biological covariates explained a lower deviance (approximately $8 \%$ of the residual deviance).

\subsection{Spatial relation between sole distribution and benthic macrofauna}

Locally adjusted regression curves of biological variables, in relation with distance to the dam, exhibited a spatial and interannual covariance between juvenile sole densities and benthic macrofauna biomasses, both being higher inside than outside the estuary (Fig. 3). Compared to July 2004, benthic biomass and YOY sole density clearly increased in July 2005. In particular, total biomass and suspensive filter feeder biomass appeared to respond similarly as juvenile sole densities, with an optimum inside the river channel in 2004 and downstream, at the estuary mouth, in 2005 (Fig. 3). Conversely, this spatial covariation was not evident for carnivorous macrobenthos. 


\section{Discussion}

Improving the management of fish stocks requires the identification of essential habitats and the assessment of their suitability and quality (Schmitten, 1999; Levin and Stunz, 2005). This study has shown that introducing the distribution and abundance of benthic macrofauna improves the value of models of common sole nursery grounds and leads to more relevant indicators of their nursery habitat.

\subsection{Identification of essential sole habitats at regional scale}

At the scale of Vilaine Bay, physical parameters, depth and sediment cover correctly reflect the distribution of YOY common sole, which are concentrated on rather shallow (less than $5 \mathrm{~m}$ depth) muddy bottoms, i.e. from Arzal dam to the estuary mouth. More generally, shallow areas covered with homogenous substratum of fine sediment were already known to be strong indicators of juvenile common sole distribution (Rogers, 1992; Gibson, 1994; Gibson and Robb, 2000; Le Pape et al., 2003b). Juvenile sole prefer these soft sediments where they can bury themselves to be less vulnerable to predators (Tanda, 1990; Dorel et al., 1991). Moreover, in shallow soft substratum, they can feed on their favourite benthic prey species (Lagardère, 1987; Le Bris and Glémarec, 1996; Amara et al., 2001). Hence, models of juvenile sole habitat suitability based on physical descriptors are appropriate for quantitative estimates of nursery habitat suitability at large scale. In addition, by coupling HSI with GIS, quantitative maps of nursery habitat have already been developed in the Eastern Channel (Riou et al., 2001; Eastwood et al., 2003) and in the Bay of Biscay (Le Pape et al., 2003b). These maps constitute real management tools, because they provide an image of potential habitats, on which habitat-restoration projects can be based (Peterson, 2003).

Depth and sediment structure, however, are only one part of a complex interaction among biotic and abiotic factors involved in habitat selection (Rogers, 1992; Gibson, 1994; Phelan et al., 2001). Sites with the same range of water depth and sediment composition may differ for instance in hydrographic conditions and, therefore, in accessibility for benthic macrofauna and juvenile sole recruits (Armonies and Reise, 2003). Consequently, a habitat, highly suitable for young sole according to abiotic descriptors, can actually be devoid of prey and juveniles (Armonies and Reise, 2003). In addition, pollution (Grall and Glémarec, 1997; Gilliers et al., 2006), excess of organic enriched mud (Jenkinson et al., 2006), and high turbidity (Marchand, 1993) in estuarine systems negatively influence the availability of prey, the behaviour and metabolism of young flatfishes. Consequently, abiotic indicators that do not account for such factors are less useful in assessing habitat quality and estimating consequences of anthropogenic pressures (Beck et al., 2001). By contrast, integrating biotic variables into HIS models improves descriptors of nursery habitat and function (Peterson et al., 2000; Beck et al., 2001; Adams et al, 2004; Le Pape et al., 2007).

\subsection{Improving identification of essential sole habitat by taking into account benthic macrofauna}

The present study showed that introducing benthic macrofauna as a quantitative parameter significantly improved the general description of sole nursery habitat obtained with physical factors. The integration of biological covariates appeared even more relevant at the restricted core nursery area scale, where physical factors were homogeneous and not discriminatory. The distribution of juvenile sole depends on habitat suitability which can vary significantly at local scales (Beck et al., 2001; Curran and Able, 2002). Integrating benthic macrofauna allows the consideration of this important local heterogeneity and results in more accurate information related to localisation and suitability of nursery grounds.

\subsection{Links between juvenile sole and benthic invertebrates: ecological explanations}

The present study determined possible links between benthic invertebrates and juvenile fishes, and thus, also provided information regarding the causality of the relation (i.e. trophic links).

Covariation between YOY sole density data and total macrobenthic or suspension feeder biomass

YOY sole abundance is positively correlated to an index of total biomass and to suspension feeder biomass at large scale and more particularly at the restricted area scale; juveniles are more numerous where total biomass of benthic invertebrates is high. This result could reflect the fact that juvenile sole behave as opportunistic feeders (Rogers, 1992, Amara et al., 2001) and prefer habitats offering a homogeneous substratum with the highest densities of polychaetes and bivalves. At the time of early juvenile settlement, they develop and survive more easily in areas where their favourite benthic preys are abundant (Zijlstra et al., 1982; van der Veer and Witte, 1993; Wennhage and Pihl, 2001). Also, other authors have demonstrated the link between benthic productivity, benthic fauna and nursery function (Gibson, 1994; Peterson et al., 2000; Beck et al., 2001; Adams et al., 2004), so that 
these correlations may appear valid. Furthermore, juvenile sole densities and biomass of benthic macrofauna had a similar distribution along the upstream/downstream gradient of the estuary in both July 2004 and 2005 and were correlated. This spatial covariance between years was probably driven by trophic processes, and reinforced the idea that these two biological variables are interrelated. Moreover, HSI model results seem to confirm that interannual variation in sole abundance is partly positively related to fluctuations in benthic biomass (Vinagre et al., 2006). As a result, although the causality of the link between sole density and benthic invertebrates was not examined here, these indicators based on benthic macrofauna could constitute a useful proxy in providing information related to sole nursery function and productivity.

\section{Co-occurrence of YOY sole and carnivorous benthic invertebrates}

In addition to physical parameters, the presence of juvenile sole is positively correlated at large scale to an index of total biomass of benthic invertebrates and even more strongly to carnivore biomass. Presence of carnivores generally involves a more complex trophic chain and an enrichment of specific diversity. Thus, carnivore biomass appears here as an indicator of favourable areas for young sole development rather than a direct ecological cause of their presence (Le Pape et al., 2007). However, despite this significant co-occurrence, no covariation between YOY sole density and carnivore biomass was found. The presence of carnivores also reinforces the idea that nursery habitats are essential food supply areas (Gibson, 1994).

\subsection{Validity of the present approach to develop juvenile sole HSI indicators in relation to monitoring requirements}

The HSI indicators, as developed in the present study, present several advantages which partly satisfy the requirements for monitoring applications. Built on aggregated trophic groups, these indicators account for robust community descriptors (Luczkovitch et al., 2002). Species play similar ecological roles (in terms of ecotrophic guilds), independently of taxonomic changes linked to biogeographical distribution (Hooper et al., 2005). Hence these indicators, already used to describe the health of marine habitats (Frid et al., 2000) and the fishing impact on benthic communities (Jennings et al., 1999), may be applied across different biogeographical contexts (Bremmer et al., 2003). Consequently, these kinds of indicators could serve as standardised diagnostic tools to estimate suitability of essential fish habitat (Vinagre et al., 2006), which is essential for ecosystemic management.

Based on benthic macrofauna, these indicators could also provide information related to habitat quality and, in particular, to human impacts on flatfish nurseries. Indeed, benthic invertebrates, which have relatively low mobility compared to fish, are locally affected by natural and anthropogenic perturbations (Pearson and Rosenberg, 1978; Grall and Glémarec, 1997), and they have already been used as proxy of the impact at sea (e.g. Grall and Glémarec, 1997; Weisberg et al., 1997; Borja et al., 2003). However, the sensitivity of the trophic guilds selected here to habitat disturbance still remains to be determined.

Before their use in monitoring systems, these indicators require validation by further surveys over more years and in different sole nursery areas, to consider temporal variability and to validate these results on other coastal and estuarine nurseries. Moreover, to gain further understanding of the correlations between benthic macrofauna and juvenile sole density, trophic links between benthos and juvenile sole will also have to be analysed to uncover the pertinent biological processes, e.g. through stomach analysis and stable isotope analysis (Darnaude et al., 2004).

Furthermore, monitoring requires practical and relatively cheap tools (Rice, 2003). While indicators involving taxonomic determination at the species level are very labour intensive, indicators developed by identifying trophic group levels may be better adapted to monitoring networks. Hence, further investigations are needed to analyse whether a more specific group, for instance molluscs (e.g. bivalves) and/or crustaceans (e.g. amphipods) for suspension feeders, could constitute a reliable indicator to describe sole habitat suitability. The simplest and easiest management tool may be represented by the total biomass of macrobenthic invertebrates, as shown by our results. Consequently, particular attention should be brought to this indicator in future research to develop management plans.

In the future, these indicators will have to be tested and extrapolated to other opportunist species to develop plurispecific suitability indices for essential fish nursery habitat (Rubec et al., 1999; Coates et al., 2007). Analysing the relation between the global nursery function and the properties of the habitat will then allow new perspectives for management of essential fish habitats (Rubec et al., 1999; Beck et al., 2001). 
Monitoring networks for the assessment of both water quality and ecological function of coastal systems are being increasingly established (Basset and Abbiati, 2004, Coates et al., 2007). From these new coastal monitoring networks, based on similar protocols as in the present study, maps of benthic invertebrates communities could be developed (Jordan et al., 2005). Then, if models linking YOY sole habitat suitability to synthetic descriptors of the benthic fauna are validated, coupling our indicators with these networks will greatly facilitate the identification and assessment of essential sole habitats in space and time.

\section{Acknowledgements}

This project was supported by the French National Programme for Coastal Ecology (PNEC) and by the French Region "Pays de la Loire". Special thanks to J.P. Bourse and its boat "La Licorne", and also C. Le Ker, P. Laffargue and C. Chevalier (Ifremer, France) for their help in the field and the laboratory analyses. The authors are also grateful to $\mathrm{S}$. Allen from the University of British Columbia (Canada) and C. Jones (Agrocampus Rennes, France and Old Dominion University, USA) for suggesting English improvements and to the two anonymous referees and M. Elliott (Institute of Estuarine and Coastal Studies, Hull, UK) for their relevant comments on the draft version of the manuscript.

\section{References}

Able, K.W., 2005. A re-examination of fish estuarine dependence: Evidence for connectivity between estuary and ocean habitats. Estuarine Coastal and Shelf Science 64, 5-17.

Adams, A.J., Locascio, J.V., Robbins, B.D., 2004. Microhabitat use by a post-settlement stage estuarine fish: evidence from relative abundance and predation among habitats. Journal of Experimental Marine Biology and Ecology 299, 17-33.

Adams, S., 2002. Biological indicators of aquatic ecosystem stress. American Fisheries Society, Bethesda, MD, $656 \mathrm{pp}$.

Anonymous, 2003. Report of the ICES advisory committees on Fishery management. ICES cooperative research report, Copenhagen, Denmark, $261 \mathrm{pp}$.

Antunes, P., Santos, R., 1999. Integrated environmental management of the oceans. Ecological Economy 31, 215-226.

Amara, R., Laffargue, P., Dewarumez, J.M., Maryniak, C., Lagardère, F., Luczac, C., 2001. Feeding ecology and growth of 0-group flatfish (sole, dab and plaice) on a nursery ground (Southern Bight of the North Sea). Journal of Fish Biology 58, 788-803.

Armonies, W., Reise, K., 2003. Empty habitat in coastal sediments for populations of macrozoobenthos. Helgoland Marine Research 56, 279-287.

Basset, A., Abbiati, M., 2004. Challenges to transitional water monitoring: ecological descriptions and scales. Aquatic Conservation 14 (1), 1-4.

Beck, M., Heck, K., Able, K., Childers, D., Eggleston, D., Gillanders, B.M., Halpern, B., Hays, C., Hostino,K., Minello, T.J., Orth, R., Sheridan, P., Weinstein, M.P., 2001. The role of nearshore ecosystems as fish and shellfish nurseries. Bioscience 51, 633-641.

Borja, A., Muxika, I., Franco, J., 2003. The application of a Marine Biotic Index to different impact sources affecting soft-bottom benthic communities along European coasts. Marine Pollution Bulletin 46, 835-845.

Bremmer, J., Rogers, S.I., Frid, C. 2003. Assessing functional diversity in marine benthic ecosystems: a comparison of approaches. Marine Ecology Progress Series 254, 11-25.

Coates, S., Waugh, A., Anwar, A., Matthew, R., 2007. Efficacy of a multi-metric index as an analysis tool for the transitional fish component of the Water Framework Directive. Marine Pollution Bulletin 55 (1-6), 225-240.

Costello, M.J., Emblow, C.S., White, R. (Ed.), 2001. European Register of Marine Species: A check-list of the marine species in Europe and a bibliography of guides to their identification. Patrimoines naturels 50, $463 \mathrm{pp}$.

Curran, M.C., Able, K.W., 2002. Annual stability in the use of Coves Near Inlets as settlement areas for Winter Flounder (Pseudopleuronectes americanus). Estuaries 25, 227-234.

Darnaude, A.M., Salen-Picard, C., Polunin, N., Harmelin-Vivien, M.L., 2004. Trophodynamic linkage between river runoff and coastal fishery yield elucidated by stable isotope data in the Gulf of Lions (NW Mediterranean). Oecologia 138, 325-332.

Dorel, D., Koutsikopoulos, C., Désaunay, Y., Marchand, J., 1991. Seasonal distribution of young sole (Solea solea (L.)) in the nursery ground of bay of Vilaine (northern bay of Biscay). Netherlands Journal of Sea Research 27 (3/4), 297-306. 
Eastwood, P.D., Meaden, G.J., Carpentier, A., Rogers, S.I., 2003. Estimating limits to the spatial extent and suitability of sole (Solea solea) nursery grounds in the Dover Strait. Journal of Sea Research 50 (2-3), 151-165.

Elliott, M., Hemimgway, K.L. (Eds), 2002. Fishes in Estuaries. Blackwell, Oxford, 636 pp.

Frid, C., Rogers, S., Nicholson, M., Ellis, J., Freeman, S., 2000. Using biological characteristics to develop new indices of ecosystem health. In: Minisymposium on defining the role of ICES in supporting biodiversity conservation, ICES CM 2000/Mini, 23pp.

Gibson, R.N., 1994. Impact of habitat quality and quantity on the recruitment of juvenile flatfishes. Netherlands Journal of Sea Research 32 (2), 191-206.

Gibson, R. N., Robb, L., 2000. Sediment selection in juvenile plaice and its behavioural basis. Journal of Fish Biology 56, 1258-1275.

Gilliers, C., Le Pape, O., Morin, J., Désaunay, Y., Amara, R., 2006. Estimation of essential fish habitat quality with indicators of fish density and growth. A study of the common sole (Solea solea, L.) on nursery grounds. Estuarine Coastal and Shelf Science 69, 96-106.

Grall, J., Glémarec, M., 1997. Biodiversité des fonds de maerl en Bretagne: approche fonctionnelle et impacts anthropiques. Vie et Milieu 47, 339-348.

Hily, C., Bouteille, M., 1999. Modifications of the specific diversity and feeding guilds in an intertidal sediment colonized by an eelgrass meadow (Zostera marina) (Brittany, France). Comptes Rendus de l'Académie des Sciences, Paris, 322, 1121-1131.

Hooper, D.U., Chapin, F.S., Ewel, J.J., Hector, A., Inchausti, P., Lavorel, S., Lawton, J.H., Lodge, D.M., Loreau, M., Naem, S., Schmid, B., Setala, H., Symstad, A.J., Vandermeer, J., Wardle, D.A., 2005. Effects of biodiversity on ecosystem functioning: a consensus on current knowledge. Ecological monographs 75 (1), 3-35.

Howell, P.T., Molnar, D.R., Harris, R.B., 1999. Juvenile winter flounder distribution by habitat type. Estuaries 22, 1090-1095.

Jenkinson, I.A., Claireaux, G., Gentien, P., 2006. Biorheological properties of intertidal organic fluff on mud flats and its modification of gill ventilation in buried sole Solea solea. Marine Biology, (on line).

Jennings, S., Lancaster, J., Woolmer, A., Cotter, J., 1999. Distribution, diversity and abundance of epibenthic fauna in the North Sea. Journal of Marine Biological Association of UK 79, 385-399.

Jordan, A., Lawler, M., Halley, V., Barrett, N., 2005. Seabed habitat mapping in the Kent group of islands and its role in marine protected area planning. Aquatic Conservation 15 (1), 51-70.

Koutsikopoulos, C., Désaunay, Y., Dorel, D., Marchand, J., 1989. The role of coastal areas in the life history of sole (Solea solea L.) in the Bay of Biscay. Topics in Marine Biology, Ros., J. D. (Ed.), Scientia Marina 53 (2-3), 567-575.

Lagardère, J.P., 1987. Feeding ecology and daily food consumption of common sole, Solea vulgaris Quensel, juveniles on the French Atlantic coast. Journal of Fish Biology 30, 91-104.

Le Bris, H., Glémarec, M., 1996. Marine and brackish ecosystems of South Brittany (Lorient and Vilaine Bays) with particular reference to the effect of the turbidity maxima. Estuarine, Coastal and Shelf Science 42, 737-753.

Le Pape, O., Baulier, L., Cloarec, A., Martin, J., Le Loc'h, F., Désaunay, Y., 2007. Habitat suitability for the juvenile common sole (Solea solea, L.) in the Bay of Biscay (France): a quantitative description using indicators based on epibenthic fauna. Journal of Sea Research 57, 126-136..

Le Pape, O., Holley, J., Guérault, D., Désaunay, Y., 2003a. Quality of coastal and estuarine essential fish habitats: estimations based on the size of juvenile common sole (Solea solea, L.). Estuarine, Coastal and Shelf Science 58, 793-803.

Le Pape, O., Chauvet, F., Mahévas, S., Lazure, P., Guérault, D., Désaunay, Y., 2003b. Quantitative description of habitat suitability for the juvenile common sole (Solea solea, L.) in the Bay of Biscay (France) and the contribution of different habitats to the adult population. Journal of Sea Research 50, 139-149.

Le Pape, O., Chauvet, F., Désaunay, Y., Guérault, D., 2003c. Relationship between interannual variations of the river plume and the extent of nursery grounds for the common sole (Solea solea, L.) in Vilaine Bay. Effects on recruitment variability. Journal of Sea Research 50, 177185.

Levin, P.S., Holmes, E.E., Kevin, R.P., Harvay, C.J., 2006. Shifts in a Pacific ocean fish assemblage: the potential influence of exploitation. Conservation Biology 20 (4), 1181-1190.

Levin, P.S., Stunz, G.W., 2005. Habitat triage for exploited fishes: Can we identify essential "Essential Fish Habitat?". Estuarine, Coastal and Shelf Science 64, 70-78. 
Luczkovitch, J.J., Ward, G.P., Johnson, J.C., Christian, R.R., Baird, B., Neckles, H., Rizzo, W.M., 2002. Determining the trophic guilds of fishes and macroinvertebrates in a seagrass food web. Estuaries 25, 1143-1163.

Marchand, J., 1991. The influence of environmental conditions on settlement, distribution and growth of 0-group sole (Solea solea (L.)) in a macrotidal estuary (Vilaine, France). Netherlands Journal of Sea Research 27 (3/4), 307-316.

Marchand, J., 1993. The influence of seasonal salinity and turbidity maximum variations on the nursery function of the Loire estuary (France). Netherlands Journal of Aquatic Ecology 27 (264), 427436.

McLusky, D.S., Elliott, M., 2004. The estuarine ecosystem: ecology, threats and management, $3^{\text {rd }}$ edn. Oxford University Press, UK.

Pearson, T.H., Rosenberg, R., 1978. Macrobenthic succession in relation to organic enrichment and pollution of the marine environment. Oceanography and Marine Pollution Annual Review 16, 229-311.

Peterson, C.H., Summerson, H.C., Thomson, E., Lenihan, H.S., Grabowski, J., Manning, L., Micheli, F., Johnson, G., 2000. Synthesis of linkages between benthic and fish communities as key to protecting essential fish habitat. Bulletin of Marine Science 66, 759-774.

Peterson, M., 2003. A conceptual view of environment-habitat-production linkages in tidal river estuaries. Revue of Fisheries Science 11 (4), 291-313.

Phelan, B.A., Manderson, J.P., Stoner, A.W., Bejda, A.J., 2001. Size-related shifts in the habitat associations of YOY winter flounder (Pseudopleuronectes americanus): field observations and laboratory experiments with sediments and prey. Journal of Experimental Marine Biology Ecology 257, 297-315.

R Development Core Team, 2006. R: a language and environment for statistical computing. R Foundation for statistical computing, Vienna, Austria. Available: http://www.r-project.org/ [accessed Mars 2006]..

Rice, J., 2003. Environment health indicators. Ocean and Coastal Management 46, 235-259.

Riou, P., Le Pape, O., Rogers, S., 2001. Relative contributions of different sole and plaice nurseries to the adult population in the Eastern Channel: application of a combined method using Generalized Linear Models and a Geographic Information System. Aquatic Living Resources $14,125-135$

Rogers, S.I., 1992. Environmental factors affecting the distribution of sole (Solea solea (L.)) within a nursery area. Netherlands Journal of Sea Research 29 (1-3), 153-161.

Rubec, P.J., Bexley, J.C.W., Norris, H., Coyne, M.S., Monaco, M.E., Smith, S.G., Ault, J.S., 1999. Suitability modelling to delineate habitat essential to sustainable fisheries. American Fisheries Society Symposium 22, 108-133.

Salas, F., Neto, J.M., Borja, A., Marques, J.C., 2004. Evaluation of the applicability of a marine biotic index to characterize the status of estuarine ecosystems: the case of Mondego estuary (Portugal). Ecological indicators 4, 215-225.

Sakamoto, Y., Ishiguro, M., and Kitagawa G., 1986. Akaike Information Criterion Statistics. D. Reidel Publishing Company, 290 pp.

Schmitten, R.A., 1999. Essential fish habitat: opportunities and challenges for the next millennium. American Fisheries Society Symposium 22, 3-10.

Tanda, M., 1990. Studies on burying ability in sand and selection to the grain size for hatchery-reared Marbled Sole and Japanese Flounder. Nippon Suisan Gakkaishi 56 (10), 1543-1548.

van der Veer, H.W., Berghahn, R., Miller, J.M., Rijnsdorp, A., 2000. Recruitment in flatfish, with special emphasis on North Atlantic species: Progress made by the flatfish symposia. ICES Journal of Marine Science 57, 202-215.

van der Veer, H.W., Witte, I. I.J., 1993. The "maximum growth/optimal food condition" hypothesis: a test for 0-group plaice Pleuronectes platessa L. in the Dutch Wadden Sea. Marine Ecology Progress Series 101, 81-90.

Vinagre, C., Fonseca, V., Cabral, H., Costa, M.J., 2006. Habitat suitability index models for the juvenile soles, Solea solea and Solea senegalensis, in the Tagus estuary: Defining variables for species management. Fisheries Research 82 (1-3), 140-149.

Weisberg, S.B., Dauer, D.M., Schaffner, L.C., Frithsen, J.B., 1997. An estuarine benthic index of biotic integrity (B-IBI) for Chesapeake Bay. Estuaries 20 (1), 149-158.

Wennhage, H., Pihl, L., 2001. Settlement patterns of newly settled plaice (Pleuronectes platessa) in a non-tidal Swedish fjord in relation to larval supply and benthic predators. Marine Biology 139, 877-889. 
Whitfield, A.K., Elliott, M., 2002. Fishes as indicators of environmental and ecological changes within estuaries: A review of progress and some suggestions for the future. Journal of fish Biology 61 (Supplement A), 229-250.

Worm, B., Barbier, E.B., Beaumont, N., Duffy, J.E., Folke, C., Halpern, B.S., Jackson, J.B.C., Lotze, H.K., Micheli, F., Palumbi, S.R., Sala, E., Selkoe, K.A., Stachowicz, J.J., Wtason, R., 2006. Impacts of Biodiversity Loss on Ocean Ecosystem Services. Science 314, 787-790.

Zijlstra, J.J., Dapper, R., Witte, J. I.J., 1982. Settlement, growth and mortality of post-larval plaice (Pleuronectes platessa L.) in the western Wadden Sea. Netherlands Journal of Sea Research $15,250-272$. 


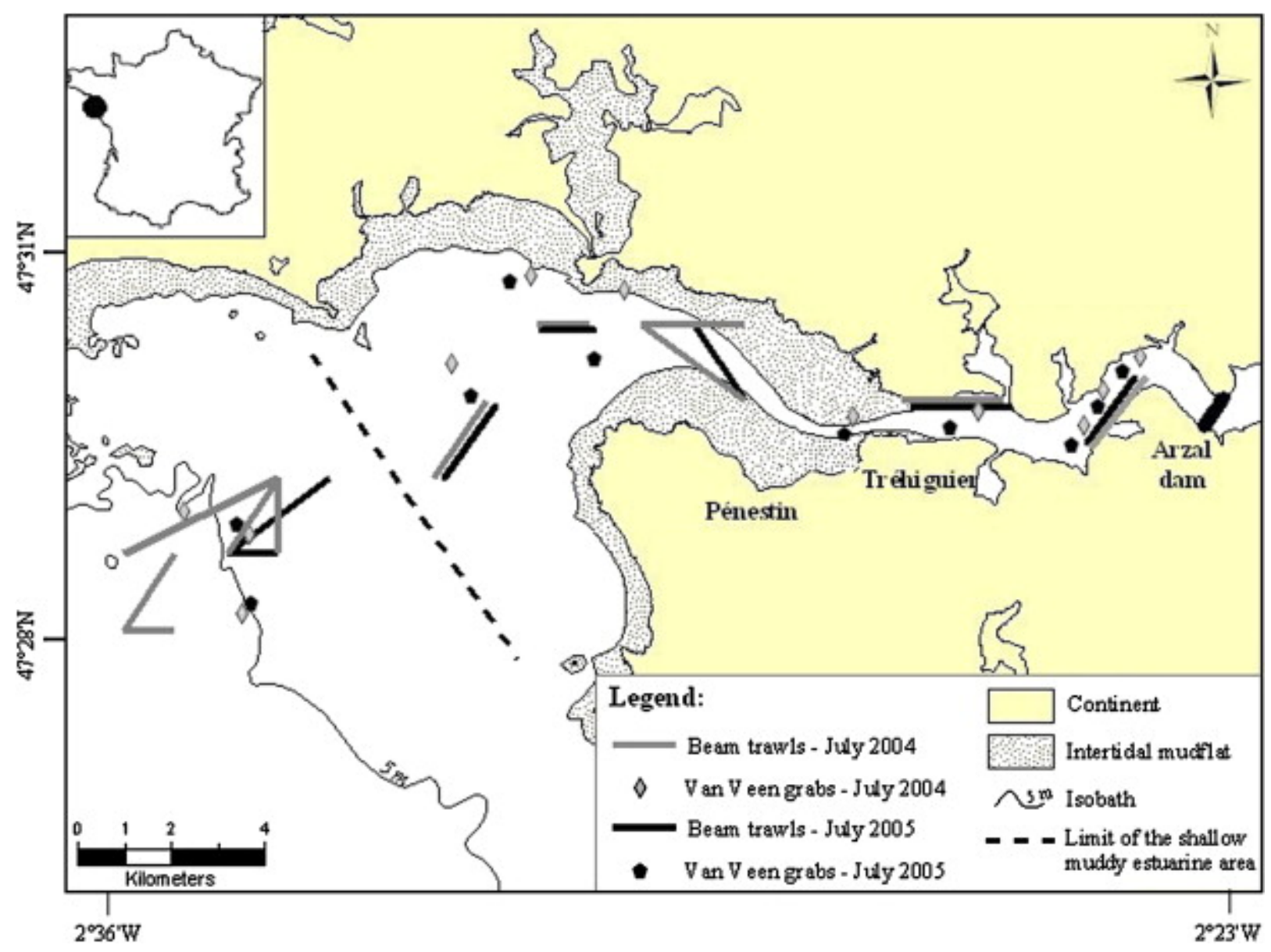

Fig. 1. Vilaine estuary and position of sampling stations. In upper right corner: general location of the study area. 


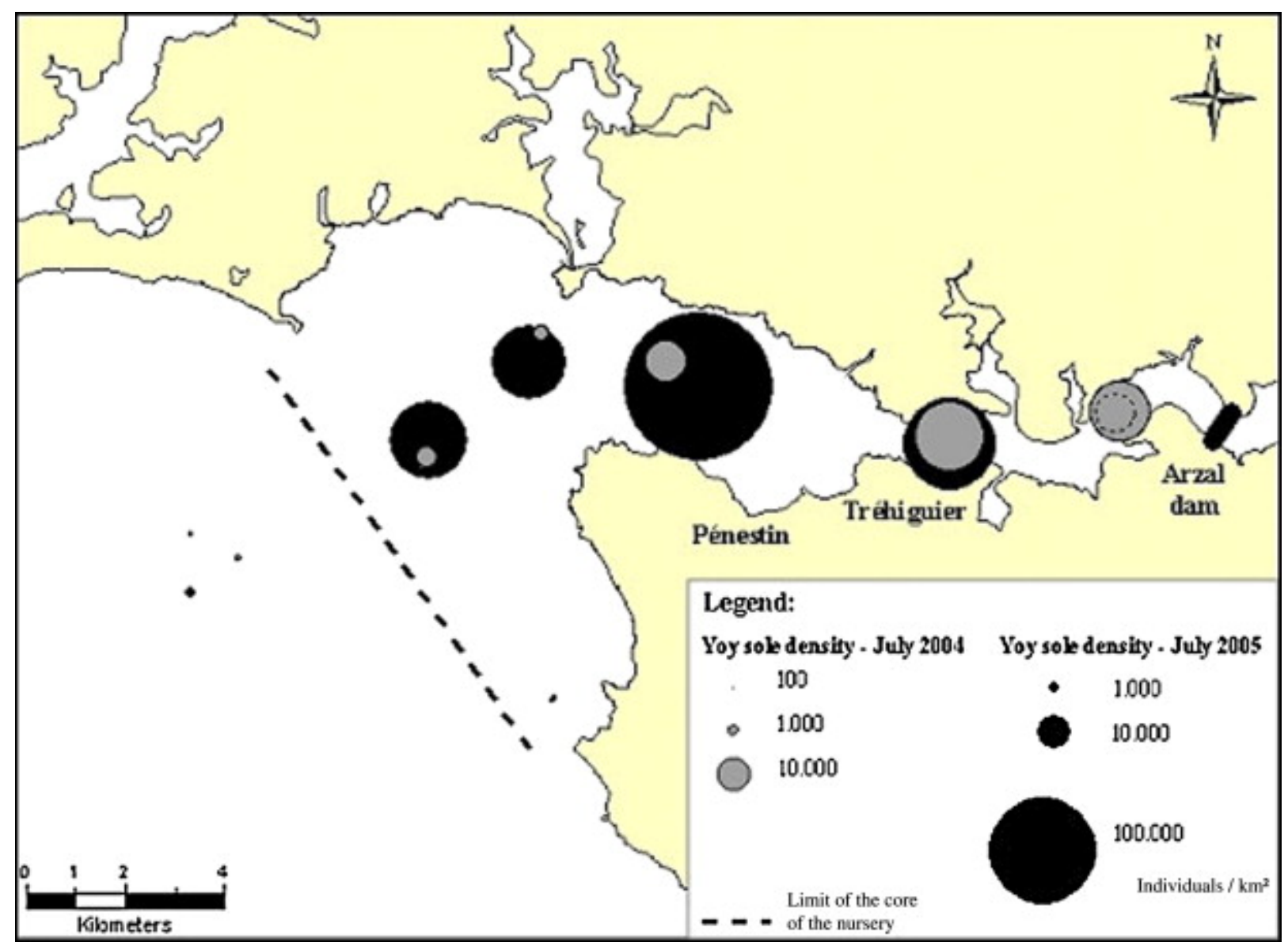

Fig. 2. Densities of trawled young-of-the-year sole during the surveys in July 2004 and 2005.

a

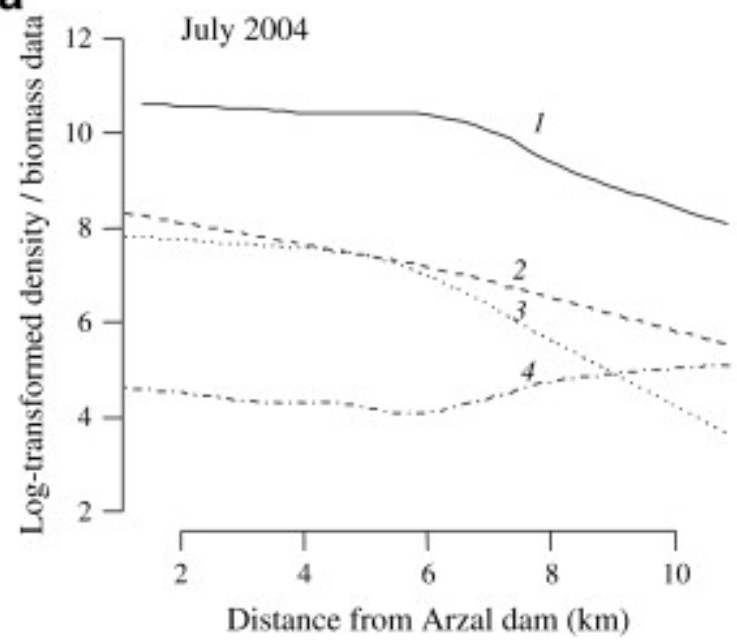

b

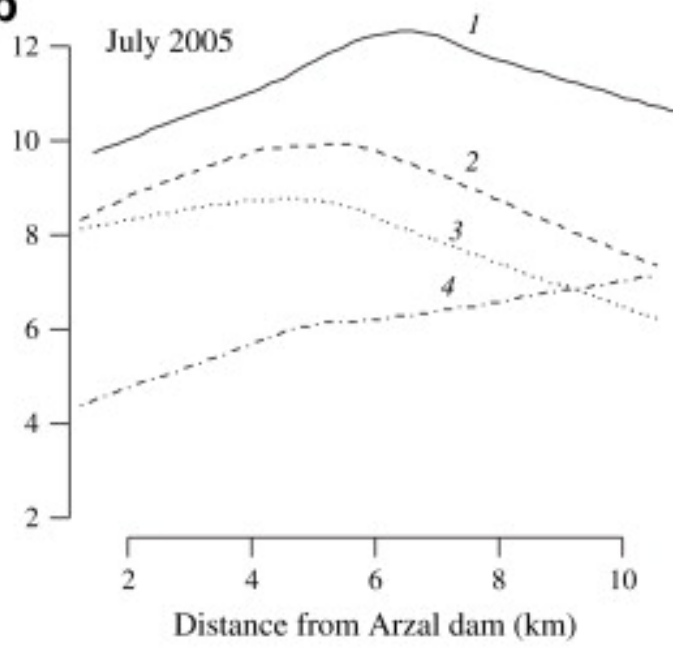

Fig. 3. As functions of distance to Arzal dam (km): spatial distribution of log-transformed YOY sole densities (individuals $/ \mathrm{km}^{2}$, continuous line numbered 1), log-transformed total macrobenthic biomass (mg AFDW) $/ \mathrm{m}^{-2}$, dashed line numbered 2), log-transformed suspensive filter feeder biomass (mg AFDW) $/ \mathrm{m}^{-2}$, point line numbered 3), log-transformed carnivore biomass (mg AFDW) $/ \mathrm{m}^{-2}$, dashed-point line numbered 4), in July 2004 (a) and in July 2005 (b). (AFDW = Ash-Free Dry Weight). 
Table 1

List of sampled benthic macrofauna species and their respective trophic group (car.: carnivore ; susp.: suspension feeder ; sel. dep.: selective deposit feeder ; non sel. dep.: non selective deposit feeder ; detri.: detritivore ; micr.: micrograzer ; scav.: scavenger). (ni: non identified).

\begin{tabular}{|c|c|c|c|c|c|c|c|}
\hline & NAME & AUTHORITY & $\begin{array}{c}\text { TROPHIC } \\
\text { GROUP }\end{array}$ & & NAME & AUTHORITY & $\begin{array}{c}\text { TROPHIC } \\
\text { GROUP }\end{array}$ \\
\hline \multicolumn{3}{|c|}{ Cnidaria - Hydrozoa } & car. & Phascolionidae & Phascolion strombus & (Montagu, 1804) & non sel. dep. \\
\hline \multicolumn{3}{|l|}{ Actiniaria } & car. & \multicolumn{4}{|c|}{ Mollusca - Gastropoda } \\
\hline Edwardsiidae & Edwardsia sp & (de Quatrefages, 1842) & car. & Cerithiidae & Bittium reticulatum & (da Costa, 1778) & micr. \\
\hline Cerianthidae & Cerianthus lloydi & (Gosse, 1859) & car. & Turritellidae & Turritella communis & (Risso, 1826) & susp. \\
\hline \multicolumn{3}{|l|}{ Nemertina } & car. & Hydrobiidae & Hydrobia ulvae & (Pennant, 1777) & micr. \\
\hline \multicolumn{4}{|c|}{ Annelida - Roaming polychaeta } & Calyptraeidae & Calyptrea chinensis & (Linné, 1758) & susp. \\
\hline Glyceridae & $\begin{array}{l}\text { Glycera unicornis } \\
\text { Glycera sp }\end{array}$ & \begin{tabular}{|l} 
(Savigny, 1818) \\
(Savigny, 1818) \\
\end{tabular} & $\begin{array}{l}\text { car. } \\
\text { car. }\end{array}$ & Nassariidae & $\begin{array}{l}\text { Nassarius pygmaeus } \\
\text { Nassarius reticulatus }\end{array}$ & $\begin{array}{l}\text { (Lamarck, 1822) } \\
\text { (Linné, 1758) } \\
\end{array}$ & 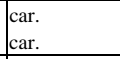 \\
\hline Goniadidae & Glycinde nordmanni & (Malmgren, 1865) & car. & Acteonidae & Acteon tornatilis & (Linné, 1758) & car. \\
\hline \multirow[t]{2}{*}{ Hesionidae } & Ophiodromus flexиosus & (Delle Chiaje,1825) & car. & Philinidae & Philine aperta & (Linné, 1767) & car. \\
\hline & Syllidia armata & (Quatrefages, 1865) & car. & Cylichnidae & Cylichna cylindracea & (Pennant, 1777) & car. \\
\hline \multirow[t]{2}{*}{ Lumbrineridae } & Lumbrineris gracilis & (Ehlers, 1868) & non sel. dep. & \multicolumn{4}{|c|}{ Mollusca - Bivalvia } \\
\hline & Lumbrineris sp & (Blainville, 1828) & non sel. dep. & \begin{tabular}{|l} 
Nuculidae \\
\end{tabular} & Nucula nitidosa & (Winckworth, 1930) & susp. \\
\hline Pholoidae & Pholoe inornata & (Johnston, 1839) & car. & Mytilidae & Mytilus edulis & (Linné, 1758) & susp. \\
\hline \multirow[t]{5}{*}{ Phyllodocidae } & Eteone longa & (Fabricius, 1780) & car. & Thyasiridae & Thyasira flexuosa & (Montagu, 1803) & sel. dep. \\
\hline & Eumida sanguinea & (Oersted, 1843) & car. & Montacutidae & Mysella bidentata & (Montagu, 1803) & sel. dep. \\
\hline & $\begin{array}{l}\text { Paranaitis kosteriensis } \\
\text { Phyllodoce laminosa }\end{array}$ & $\begin{array}{l}\text { (Malmgren, 1867) } \\
\text { (Savigny, 1818) }\end{array}$ & $\begin{array}{l}\text { car. } \\
\text { car. }\end{array}$ & Cardiidae & $\begin{array}{l}\text { Acanthocardia tuberculata } \\
\text { Cerastoderma glaucum }\end{array}$ & \begin{tabular}{|l} 
(Linné, 1758) \\
(Poiret, 1789)
\end{tabular} & $\begin{array}{l}\text { susp. } \\
\text { susp. }\end{array}$ \\
\hline & Phyllodoce lineata & (Clarapède, 1870) & car. & Mactridae & Spisula subtruncata & (da Costa, 1778) & susp. \\
\hline & Phyllodoce sp & (Linnaeus, 1791) & car. & Pharidae & Phaxas pellucidus & (Pennant, 1777) & susp. \\
\hline \multirow[t]{3}{*}{ Polynoidae } & Harmothoe impar & (Johnston, 1839) & car. & Tellinidae & Macoma balthica & (Linné, 1758) & susp. \\
\hline & Malmgreniella lunulata & (Delle Chiaje, 1830) & car. & Scorbiculariidae & Scrobicularia plana & (da Costa, 1778) & sel. dep. \\
\hline & Harmothoe sp & (Kinberg, 1855) & car. & Semelidae & Abra alba & (Wood W., 1802) & sel. dep. \\
\hline \multirow[t]{3}{*}{ Nephtyidae } & Nephtys sp & (Cuvier, 1833) & car. & & Abra nitida & (Müller O. F., 1776) & sel. dep. \\
\hline & & $\begin{array}{l}\text { (Savigny, 1818) } \\
\text { (McIntosh, 1900) }\end{array}$ & $\begin{array}{l}\text { car. } \\
\text { car. }\end{array}$ & Veneridae & $\begin{array}{l}\text { Chamelea striatula } \\
\text { Tapes decussata }\end{array}$ & $\begin{array}{l}\text { (da Costa, 1778) } \\
\text { (Linné, 1758) }\end{array}$ & $\begin{array}{l}\text { susp. } \\
\text { susp. }\end{array}$ \\
\hline & Nephtys kersivalensis & (McIntosh, 1908) & car. & Petricolidae & Mysia undata & (Pennant, 1777) & sel. dep. \\
\hline \multirow[t]{3}{*}{ Nereidae } & ni & (Johnston, 1865) & detri. & Myidae & Mya arenaria & (Linné, 1758) & susp. \\
\hline & Nereis diversicolor & (O.F. Müller, 1776) & detri. & Corbulidae & Corbula gibba & (Olivi, 1792) & susp. \\
\hline & Nereis $s p$ & (Linnaeus, 1758) & detri. & Thraciidae & Thracia papyracea & (Poli, 1791) & susp. \\
\hline \multirow[t]{2}{*}{ Onuphidae } & Aponuphis bilineata & (Baird, 1870) & car. & Pandoridae & Pandora pinna & (Montagu, 1803) & susp. \\
\hline & Diopatra neapolitana & (Delle Chiaje, 1841) & car. & Pycnogonida & & & \\
\hline Sigalionidae & Labioleanira yhleni & (Malmgren, 1867) & car. & \begin{tabular}{|l} 
Phoxichilidiidae \\
\end{tabular} & Anoplodactylus sp & (Wilson, 1878) & car. \\
\hline & Sthenelais boa & (Johnston, 1833) & car. & Crustacea - Cope & oda & & \\
\hline Syllidae & Autolytus $s p$ & (Grube, 1850) & car. & Copepoda & ni & & susp. \\
\hline Annelida - Seden & tary polychaeta & & & Crustacea - Cum & & & \\
\hline Ampharetidae & $\begin{array}{l}\text { Ampharete acutifrons } \\
\text { Melinna palmata }\end{array}$ & \begin{tabular}{|l} 
(Grube, 1860) \\
(Grube, 1870)
\end{tabular} & $\begin{array}{l}\text { sel. dep. } \\
\text { sel. dep. }\end{array}$ & Bodotriidae & \begin{tabular}{|l} 
Bodotria scorpioides \\
Iphinoe trispinosa
\end{tabular} & \begin{tabular}{|l} 
(Montagu, 1804) \\
(Goodsir, 1843)
\end{tabular} & $\begin{array}{l}\text { sel. dep. } \\
\text { sel. dep. }\end{array}$ \\
\hline Aphroditidae & ni & & car. & & Iphinoe $s p$ & (Bate, 1856) & sel. dep. \\
\hline Capitellidae & \begin{tabular}{|l} 
ni \\
Heteromastus filiformis \\
Mediomastus fragilis
\end{tabular} & \begin{tabular}{|l} 
(Grube, 1862) \\
(Clarapède, 1864) \\
(Rasmussen, 1973)
\end{tabular} & $\begin{array}{l}\text { non sel. dep. } \\
\text { non sel. dep. } \\
\text { non sel. dep. }\end{array}$ & Diastylidae & \begin{tabular}{|l} 
Diastylis bradyi \\
Diastylis laevis \\
Diastylis rugosa \\
\end{tabular} & $\begin{array}{l}\text { (Norman, 1879) } \\
\text { (Norman, 1869) } \\
\text { (Sars, 1865) } \\
\end{array}$ & $\begin{array}{l}\text { sel. dep. } \\
\text { sel. dep. } \\
\text { sel. dep. }\end{array}$ \\
\hline & Notomastus latericeus & (M. Sars, 1851) & non sel. dep. & Crustacea - Amp & ipoda & & \\
\hline Chaetopteridae & Chaetopterus sp & (Cuvier, 1827) & susp. & Caprellidae & ni & (Leach, 1814) & car. \\
\hline & Spiochaetopterus costarum & (Clarapède, 1868) & susp. & Ampeliscidae & Ampelisca brevicornis & (Costa, 1853) & susp. \\
\hline Cirratulidae & Chaetozone gibber & (Woodham \& Chambers, 1994) & sel. dep. & & Ampelisca spinimana & (Chevreux, 1900) & susp. \\
\hline Flabelligeridae & \begin{tabular}{|l|} 
Diplocirrus glaucus \\
Pherusa monolifera
\end{tabular} & \begin{tabular}{|l|} 
(Malmgren,1867) \\
(Delle Chiaje, 1841) \\
\end{tabular} & \begin{tabular}{|l} 
car. \\
sel. dep.
\end{tabular} & & $\begin{array}{l}\text { Ampelisca spinipes } \\
\text { Ampelisca sp }\end{array}$ & $\begin{array}{l}\text { (Boeck, 1861) } \\
\text { (Kröyer, 1842) }\end{array}$ & $\begin{array}{l}\text { susp. } \\
\text { susp. }\end{array}$ \\
\hline Magelonidae & $\begin{array}{l}\text { ni } \\
\text { Magelona alleni }\end{array}$ & (Wilson, 1958) & $\begin{array}{l}\text { sel. dep. } \\
\text { sel. dep. }\end{array}$ & Corophiidae & \begin{tabular}{|l|}
$\begin{array}{l}\text { Corophium volutator } \\
\text { Siphonoecetes kroyeranus }\end{array}$ \\
\end{tabular} & \begin{tabular}{|l} 
(Pallas, 1766) \\
(Bate, 1856) \\
\end{tabular} & \begin{tabular}{|l} 
susp. \\
detri.
\end{tabular} \\
\hline & Magelona sp & (Müller, 1858) & sel. dep. & Eusiridae & Apherusa bispinosa & (Bate, 1857) & car. \\
\hline Maldanidae & Clymenura clypeata & (de Saint Joseph, 1894) & sel. dep. & Isaeidae & Photis longicaudata & (Bate \& Westwood, 1862) & detri. \\
\hline & Euclymene oerstedi & (Clarapède, 1863) & sel. dep. & Leucothoidae & Leucothoe incisa & (Robertson, 1892) & sel. dep. \\
\hline Orbiniidae & Scoloplos armiger & (O.F. Müller, 1776) & non sel. dep. & Melitidae & Abludomelita obtusata & (Montagu, 1813) & detri. \\
\hline Pectinariidae & Pectinaria koreni & (Malmgren, 1866) & non sel. dep. & Crustacea - Deca & oda & & \\
\hline Poecilochaetidae & Poecilochaetus serpens & (Allen, 1904) & sel. dep. & Crangonidae & Crangon crangon & (Linnaeus, 1758) & car. \\
\hline Scalibregmatidae & Scalibregma inflatum & (Rathke, 1843) & non sel. dep. & & Philocheras trispinosus & (Hailstone, 1835) & car. \\
\hline Spionidae & \begin{tabular}{|l} 
ni \\
Dipolydora caeca \\
Polydora sp
\end{tabular} & $\begin{array}{l}\text { (G.O. Sars, 1872) } \\
\text { (Oersted, 1843) } \\
\text { (Johnston, 1838) }\end{array}$ & $\begin{array}{l}\text { sel. dep. } \\
\text { sel. dep. } \\
\text { sel. dep. }\end{array}$ & Paguridae & $\begin{array}{l}\text { Anapagurus hyndmanni } \\
\text { Pagurus bernhardus } \\
\text { Pagurus cuanensis }\end{array}$ & \begin{tabular}{|l} 
Bell, 1845) \\
(Linnaeus, 1758) \\
(Bell, 1845) \\
\end{tabular} & $\begin{array}{l}\text { scav. } \\
\text { scav. } \\
\text { scav. }\end{array}$ \\
\hline & Prionospio steenstrupi & (Malmgren, 1867) & sel. dep. & Porcellanidae & Pisidia longicornis & (Linnaeus, 1767) & susp. \\
\hline & Spiophanes bombyx & (Claparède, 1870) & $\begin{array}{l}\text { sel. dep. } \\
\text { sel. dep. }\end{array}$ & Portunidae & Carcinus maenas & (Linnaeus, 1758) & car. \\
\hline Sternaspidae & Sternaspis scutata & (Ranzani, 1817) & sel. dep. & Pinnotheridae & Asthenognathus atlanticus & (Monod, 1933) & car. \\
\hline Terebellidae & Amaeana trilobata & (M. Sars, 1863) & sel. dep. & Phoronida & & & \\
\hline & Amphitrite sp & (O.F. Müller, 1771) & sel. dep. & Phoronidae & Phoronis sp & & susp. \\
\hline & Lanice conchylega & (Pallas, 1766) & sel. dep. & Echinodermata - & phiurida & & \\
\hline & Polycirrus aurantiacus & (Grube, 1860) & sel. dep. & Amphiuridae & ni & (Ljungman, 1867) & susp. \\
\hline Oweniidae & Owenia fusiformis & (Delle Chiaje, 1842) & sel. dep. & & Amphiura brachiata & (Montagu, 1804) & susp. \\
\hline Paraonidae & Paradonis armata & (Glémarec, 1966) & sel. dep. & Echinodermata - & Iolothuroidea & & \\
\hline & Paradoneis lyra & (Southern, 1914) & sel. dep. & Cucumariidae & Leptopentacta elongata & (Düben \& Koren, 1846) & susp. \\
\hline & Paraonis uncinatus & (Hartman, 1965) & sel. dep. & Pisces & & & \\
\hline Sipuncles & & & & Gobiidae & Pomatoschistus sp & (Gill, 1863) & car. \\
\hline
\end{tabular}


Table 2

Analysis of deviances for the two parts of the delta log-normal Generalized Linear Model. Columns indicate residual degrees of freedom (DoF), Akaike

Information criterion (AIC); explained deviance for each added variable; residual deviance of the model; NS = Non significant at a $5 \%$ level.

\begin{tabular}{|c|c|c|c|c|c|c|c|c|}
\hline & \multicolumn{4}{|c|}{ Binomial Model (0/1 YOY sole) } & \multicolumn{4}{|c|}{ Positive values Model (YOY sole+) } \\
\hline Added variable & DoF & AIC & $\begin{array}{c}\text { Explained } \\
\text { deviance }\end{array}$ & $\begin{array}{l}\text { Residual } \\
\text { deviance }\end{array}$ & DoF & AIC & $\begin{array}{l}\text { Explained } \\
\text { deviance }\end{array}$ & $\begin{array}{l}\text { Residual } \\
\text { deviance }\end{array}$ \\
\hline \multicolumn{9}{|c|}{ TOTAL AREA } \\
\hline \multicolumn{9}{|c|}{ Model 1 : YOY-sole $\sim$ Bathymetry \& Sediment + Benthic macrofauna log-transformed biomasses } \\
\hline Null & 73 & 101.2 & & 54.5 & 64 & 472.3 & & 185.2 \\
\hline + Bathymetry \& Sediment & 69 & 34.2 & 28.3 & 26.2 & 60 & 187.3 & 125.3 & 59.9 \\
\hline+ Total biomass & 68 & 32.2 & 4 & 22.2 & 59 & 178.5 & 9.4 & 50.5 \\
\hline or + Suspensive filter feeders & 68 & & $N S$ & & 59 & 181.3 & 7.1 & 52.8 \\
\hline+ Carnivores & 68 & 22.2 & 14 & 12.19 & 59 & & NS & \\
\hline \multicolumn{9}{|c|}{ Model 2 : YOY-sole $\sim$ Year + Bathymetry \& Sediment + Benthic macrofauna log-transformed biomasses } \\
\hline Null & 73 & 101.2 & & 54.5 & 64 & 472.3 & & 185.2 \\
\hline+ Year & 71 & & NS & & 62 & 248.5 & 19.6 & 165.6 \\
\hline + Bathymetry \& Sediment & \multirow{4}{*}{\multicolumn{4}{|c|}{ Equals model 1}} & 59 & 172.9 & 119.3 & 46.3 \\
\hline+ Total biomass & & & & & 58 & 168.7 & 4.3 & 42 \\
\hline or + Suspensive filter feeders & & & & & 58 & 170.5 & 3 & 43.2 \\
\hline + Carnivores & & & & & 58 & & NS & \\
\hline \multicolumn{9}{|c|}{ MUDDY COMPARTMENT (restricted core nursery area) } \\
\hline \multicolumn{9}{|c|}{ Model 3 : YOY-sole Benthic macrofauna log-transformed biomasses } \\
\hline Null & & & & & 54 & 404.4 & & 57.9 \\
\hline \multirow{2}{*}{\begin{tabular}{|l|l|} 
or & + Total biomass \\
\cline { 2 - 2 } & + Suspensive filter feeders \\
\end{tabular}} & & & & & 52 & 154.6 & 8.4 & 49.5 \\
\hline & & & & & 52 & 156.2 & 6.9 & 51.1 \\
\hline \multicolumn{9}{|c|}{ Model 4 : YOY-sole $\sim$ Year + Benthic macrofauna log-transformed biomasses } \\
\hline Null & & & & & 54 & 404.4 & & 57.9 \\
\hline+ Year & & & & & 52 & 154 & 8.9 & 49 \\
\hline \multirow{2}{*}{\begin{tabular}{l|l} 
or & + Total biomass \\
\cline { 2 - 2 } & + Suspensive filter feeders
\end{tabular}} & & & & & 51 & 151 & 4.4 & 44.7 \\
\hline & & & & & 51 & 151.6 & 3.9 & 45.2 \\
\hline
\end{tabular}

